UDC 53.072; 53:681.3

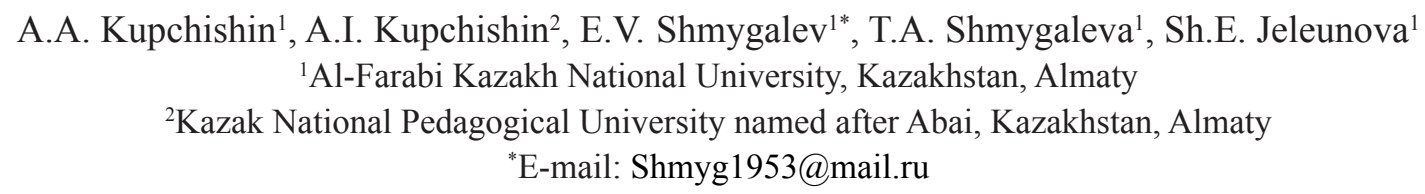

\title{
Computer modeling of radiating formation of defects processes in copper
}

\begin{abstract}
Processes of radiation formation of defects in the copper irradiated by various ions are considered in work. The algorithm for calculation of cascadely - probabilistic functions depending on number of interactions and depth of penetration of particles, concentration of radiating defects is developed, computations are lead, the regularities arising at calculations of cascadely - probabilistic functions, concentration of radiating defects at an ionic irradiation in copper are revealed.
\end{abstract}

Keywords: modeling, defects, copper, ions, modeling.

\section{Introduction}

For calculation CPF the following modernized formula convenient for computation is received:

$$
\psi_{n}\left(h^{\prime}, h, E_{0}\right)=\prod_{i=1}^{n}\left[\left(\frac{\frac{\ln \left(\frac{E_{0}-k h^{\prime}}{E_{0}-k h}\right)}{a k}-\left(h-h^{\prime}\right)}{\lambda_{0} i}\right) * \exp \left(\frac{h-h^{\prime}}{\lambda_{0}}-\frac{1}{\lambda_{0} a k}\left(\frac{E_{0}-k h^{\prime}}{E_{0}-k h}\right)\right)\right.
$$

where $\mathrm{n}$ is the number of interactions, $\mathrm{h}, \mathrm{h}$ are depths of generation and registration of an ion accordingly, $\lambda_{0}, a, E_{0}, k$ are parameters of approximation.

The approximation expression 6.64 from [1] was used to find parameters of approximation. Approximation dependences $\sigma$ from $\mathrm{h}$ are resulted in picture 2. At selection approximation curves there are some features and complexities. We note them.

1. The basic complexity consists in selection of parameters of the analytical expression describing calculated sections of interactions.

2. After a choice approximation formula in the left part of expression we have values of sections which orders increase to proportionally atomic weight from up to $10^{11}$, and in the right part there are very small values of depths from up to $\mathrm{cm}$, and with an increase of interaction section of depth decrease even more strongly.

3. As the step on depth is non-uniform, it is necessary to set very well initial data $s_{0}, a, E_{0}, k$.

4. In some cases approximation formula for ions comes in the formula for protons and alpha particles. It occurs when atomic weight of a flying particle less or is equal to atomic weight of a target.

Results of CPF calculations depending on number of the interactions, calculated under the formula 1 , are presented in tables 1-5, depending on depth of penetration - in tables 6-9. 


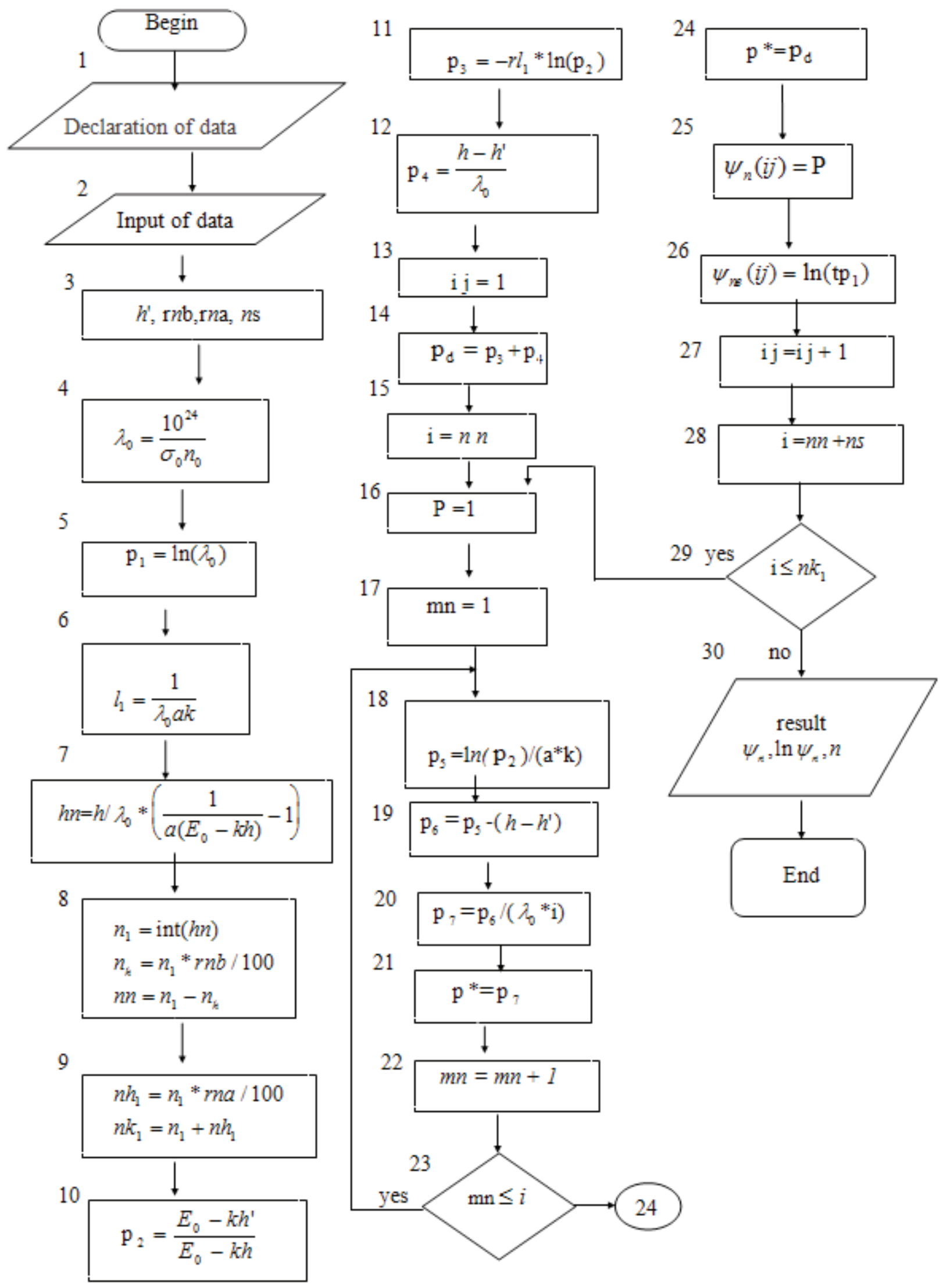

Figure 1 - The block diagram of algorithm of calculation $\psi_{n}\left(h^{\prime}, h, E_{0}\right)$ depending on number of interactions КазҰУ хабаршысы. Химия сериясы. №4 (68). 2012 


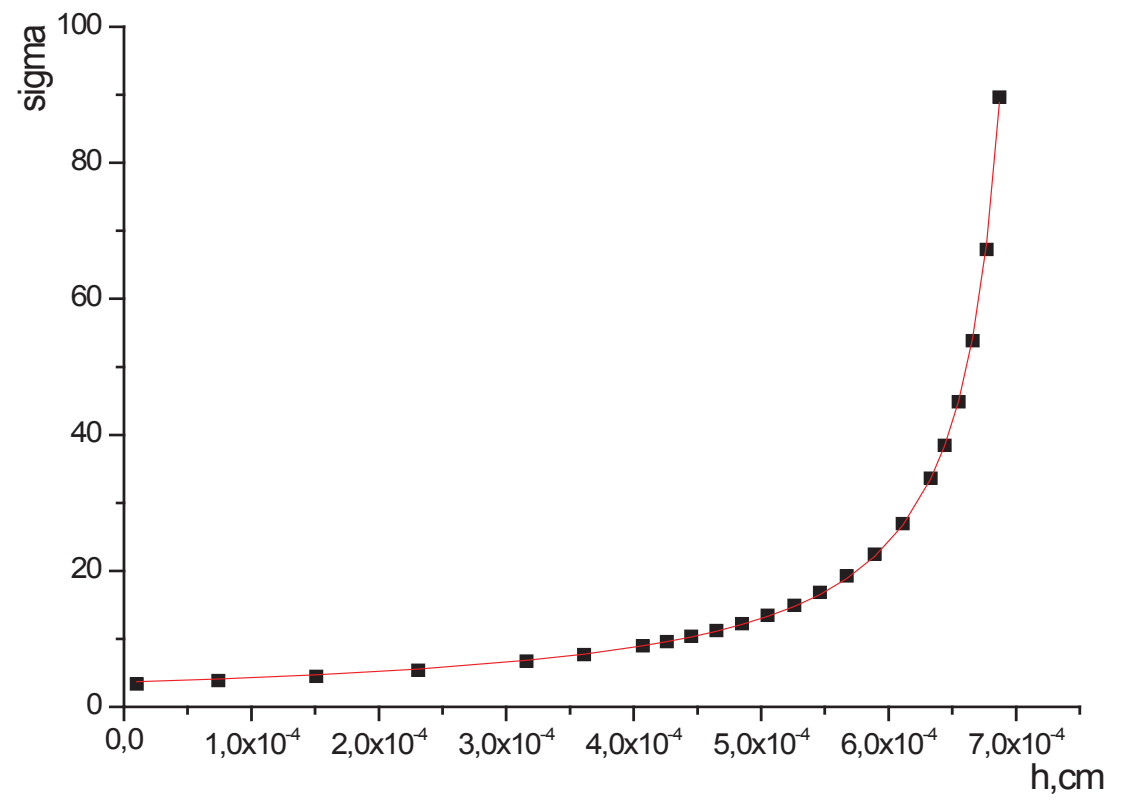

Figure 2 - Approximation of the modified section of cascadely - probabilistic function for nitrogen in copper at $\mathrm{E}_{0}=$ $800 \mathrm{keV}$. Points - the rated data of section dependences from depth, a continuous line - approximation

Table 1 - Dependence of percent of displacement of the left and right borders of result area on number of interactions for nitrogen in copper at $\mathrm{E}_{0}=1000 \mathrm{keV}$

\begin{tabular}{|c|c|c|c|c|}
\hline$h^{*} 10^{4}, \mathrm{~cm}$ & $\mathrm{~B}_{1}, \%$ & $\mathrm{~B}_{2}, \%$ & $N_{n}$ & $\mathrm{~B}_{3}, \%$ \\
\hline 1 & 43,25 & 38 & 18 & 81,25 \\
\hline 3 & 40,2 & -5 & 35 & 35,2 \\
5 & 50,65 & $-33,5$ & 50 & 17,15 \\
\hline 7 & 68,25 & $-61,2$ & 70 & 7,05 \\
\hline
\end{tabular}

Table 2 - Dependence of percent of displacement of the left and right borders of result area on number of interactions for aluminum in copper at $\mathrm{E}_{0}=1000 \mathrm{keV}$

\begin{tabular}{|c|c|c|c|c|}
\hline$h * 10^{4}, \mathrm{~cm}$ & $\mathrm{~B}_{1}, \%$ & $\mathrm{~B}_{2}, \%$ & $N_{n}$ & $\mathrm{~B}_{3}, \%$ \\
\hline 1 & 21 & 8 & 50 & 29 \\
\hline 2 & 28 & -8 & 100 & 20 \\
\hline 3 & 35 & -10 & 100 & 25 \\
\hline 4 & 46 & -38 & 150 & 8 \\
\hline 5 & 63 & -58 & 200 & 5 \\
\hline
\end{tabular}

Table 3 - Dependence of percent of displacement of the left and right borders of result area on number of interactions for the titan in copper at $\mathrm{E}_{0}=1000 \mathrm{keV}$

\begin{tabular}{|c|c|c|c|c|}
\hline$h^{*} 10^{5}, \mathrm{~cm}$ & $\mathrm{~B}_{1}, \%$ & $\mathrm{~B}_{2}, \%$ & $N_{n}$ & $\mathrm{~B}_{3}, \%$ \\
\hline 1 & 23 & 27 & 33 & 50 \\
\hline 3 & 16,4 & 10 & 55 & 26,4 \\
\hline 5 & 16,4 & 4 & 75 & 20,4 \\
\hline 7 & 17,95 & -2 & 90 & 15,95 \\
\hline 9 & 20,23 & -7 & 100 & 13,23 \\
\hline 10 & 21,55 & -9 & 110 & 12,55 \\
\hline
\end{tabular}


Table 4 - Dependence of percent of displacement of the left and right borders of result area on number of interactions for copper in copper at $\mathrm{E}_{0}=1000 \mathrm{keV}$

\begin{tabular}{|c|c|c|c|c|}
\hline$h * 10^{5}, \mathrm{~cm}$ & $\mathrm{~B}_{1}, \%$ & $\mathrm{~B}_{2}, \%$ & $N_{n}$ & $\mathrm{~B}_{3}, \%$ \\
\hline 5 & 17,53 & -5 & 100 & 12,53 \\
\hline 10 & 27,85 & -21 & 150 & 6,85 \\
\hline 15 & 41,4 & $-37,35$ & 200 & 4,05 \\
\hline 20 & 59,17 & -57 & 275 & 2,17 \\
\hline 25 & 88,16 & $-87,76$ & 400 & 0,4 \\
\hline
\end{tabular}

Table 5 - Dependence of percent of displacement of the left and right borders of result area on depth of penetration for aluminum in copper at $\mathrm{E}_{0}=100 \mathrm{keV}$

\begin{tabular}{|c|c|c|c|c|c|}
\hline$h^{*} 10^{5}, \mathrm{~cm}$ & $h / \lambda, \mathrm{cm}$ & $\mathrm{C}_{1}, \%$ & $\mathrm{C}_{2}, \%$ & $N_{h}$ & $\mathrm{C}_{3}, \%$ \\
\hline 1 & 1807 & 4,5 & 26 & 35 & 30,5 \\
\hline 2 & 4578 & $-10,85$ & 28 & 75 & 17,15 \\
\hline 3 & 9352 & $-22,85$ & 32 & 150 & 9,15 \\
\hline 4 & 19511 & $-27,75$ & 30,85 & 460 & 3,1 \\
\hline
\end{tabular}

Table 6 - Dependence of percent of displacement of the left and right borders of result area on depth of penetration for aluminum in copper at $\mathrm{E}_{0}=100 \mathrm{keV}$

\begin{tabular}{|c|c|c|c|c|c|}
\hline$h^{*} 10^{5}, \mathrm{~cm}$ & $h / \lambda, \mathrm{cm}$ & $\mathrm{C}_{1}, \%$ & $\mathrm{C}_{2}, \%$ & $N_{h}$ & $\mathrm{C}_{3}, \%$ \\
\hline 1 & 1807 & 4,5 & 26 & 35 & 30,5 \\
\hline 2 & 4578 & $-10,85$ & 28 & 75 & 17,15 \\
\hline 3 & 9352 & $-22,85$ & 32 & 150 & 9,15 \\
\hline 4 & 19511 & $-27,75$ & 30,85 & 460 & 3,1 \\
\hline
\end{tabular}

Table 7 - Dependence of percent of displacement of the left and right borders of result area on depth of penetration for the titan in copper at $\mathrm{E}_{0}=1000 \mathrm{keV}$

\begin{tabular}{|c|c|c|c|c|c|}
\hline$h^{*} 10^{5}, \mathrm{~cm}$ & $h / \lambda, \mathrm{cm}$ & $\mathrm{C}_{1}, \%$ & $\mathrm{C}_{2}, \%$ & $N_{h}$ & $\mathrm{C}_{3}, \%$ \\
\hline 1 & 754 & 19,3 & 30 & 20 & 49,3 \\
\hline 3 & 2406 & 7,5 & 18 & 40 & 25,5 \\
\hline 5 & 4284 & 1,5 & 18,5 & 55 & 20 \\
\hline 7 & 6436 & $-3,6$ & 19,1 & 75 & 15,5 \\
\hline 9 & 8928 & -8 & 21 & 95 & 13 \\
\hline 10 & 10327 & $-10,2$ & 22,2 & 100 & 12 \\
\hline 15 & 19485 & -20 & 27,5 & 160 & 7,5 \\
\hline 20 & 34993 & $-27,2$ & 31,3 & 300 & 4,1 \\
\hline 25 & 66944 & $-27,42$ & 28,7 & 1000 & 1,28 \\
\hline
\end{tabular}

Table 8 - Dependence of percent of displacement of the left and right borders of result area on depth of penetration for the silver in copper at $\mathrm{E}_{0}=1000 \mathrm{keV}$

\begin{tabular}{|c|c|c|c|c|c|}
\hline$h^{*} 10^{5}, \mathrm{cM}$ & $h / \lambda, \mathrm{cm}$ & $\mathrm{C}_{1}, \%$ & $\mathrm{C}_{2}, \%$ & $N_{h}$ & $\mathrm{C}_{3}, \%$ \\
\hline 1 & 7273 & 2,5 & 12 & 75 & 14,5 \\
\hline 3 & 26424 & $-9,4$ & 17 & 170 & 7,6 \\
5 & 54657 & $-18,57$ & 23,5 & 260 & 4,93 \\
\hline 7 & 98432 & $-25,95$ & 28,9 & 450 & 2,95 \\
\hline 9 & 172238 & $-30,31$ & 31,9 & 950 & 1,59 \\
\hline 10 & 230762 & $-30,57$ & 31,65 & 1250 & 1,08 \\
\hline 11 & 316697 & $-28,91$ & 29,52 & 2500 & 0,61 \\
\hline 13 & 705860 & $-18,1675$ & 18,218 & 30000 & 0,0505 \\
\hline
\end{tabular}


Table 9 - Dependence of percent of displacement of the left and right borders of result area on depth of penetration for gold in copper at $\mathrm{E}_{0}=1000 \mathrm{keV}$

\begin{tabular}{|c|c|c|c|c|c|}
\hline$h^{*} 10^{5}, \mathrm{~cm}$ & $h / \lambda, \mathrm{cm}$ & $\mathrm{C}_{1}, \%$ & $\mathrm{C}_{2}, \%$ & $N_{h}$ & $\mathrm{C}_{3}, \%$ \\
\hline 1 & 33297 & $-7,6$ & 14,5 & 175 & 6,9 \\
\hline 2 & 84267 & $-17,5$ & 21,5 & 350 & 4 \\
\hline 3 & 161131 & $-24,8$ & 27,25 & 575 & 2,45 \\
\hline 4 & 278147 & $-29,95$ & 31,6 & 900 & 1,65 \\
\hline 6 & 772357 & $-32,6$ & 33,1 & 3000 & 0,5 \\
\hline 7 & 1362072 & $-27,997$ & 28,18 & 8000 & 0,183 \\
\hline 8 & 2810940 & $-17,6645$ & 17,6804 & 90000 & 0,0159 \\
\hline
\end{tabular}

\section{Results and Discussion}

Concentration of radiating defects is calculated under the formula 6.80 of [1], results of calculations are presented in table 10 . The regularities arising at a finding of result area are revealed. We note some of them.

1. With reduction of initial energy of a primary particle the interval of result area is displaced to the right, values of concentration of radiating defects increase.
2. Depending on depth of penetration the initial and final values of number of interactions increase, the interval of result area $n_{0} n_{1}$ ) also increases and is displaced to the right.

3. With an increase of atomic number of a flying particle the interval of result area significantly is displaced to the right and increases, value of concentration in a point of a maximum and values of concentration strongly increase.

Table 10 - Borders of a definition range of concentration of radiating defects for nitrogen in copper at $\mathrm{E}_{\mathrm{c}}=200 \mathrm{keV}, \mathrm{E}_{0}=$ $1000 \mathrm{keV}$

\begin{tabular}{|c|c|c|c|c|}
\hline $\mathrm{h}^{*} 10^{4}, \mathrm{~cm}$ & $\mathrm{C}_{\mathrm{k}}, \mathrm{cm}$ & $\mathrm{E}_{0}, \mathrm{keV}$ & $\mathrm{n}_{0}$ & $\mathrm{n}_{1}$ \\
\hline 0,1 & 415,97 & 1000 & 1 & 58 \\
\hline 0,69 & 410,80 & 900 & 241 & 518 \\
\hline 1,39 & 402,28 & 800 & 1036 & 1550 \\
\hline 2,13 & 384,07 & 700 & 1527 & 2150 \\
\hline 2,90 & 348,20 & 600 & 2087 & 2777 \\
\hline 3,70 & 279,72 & 500 & 2750 & 3569 \\
\hline 4,56 & 146,82 & 400 & 3118 & 3955 \\
\hline 5,0 & 34,15 & 350 & 3534 & 4413 \\
\hline
\end{tabular}

\section{References}

1 Kupchishin A.I., Kylyshkanov M., Shmygaleva T.A., etc. Modelling on the PC and experimental researches of radiating processes in iron and firm alloys. - Almaty, Abay KazNAU, Al-Farabi KazNU SRI of ETP, Open Company "KAMA", 2010. - P. 263.

А.И. Купчишин, А.А. Купчишин, Т.А. Шмыгалева, Е.В. Шмыгалев, Ш.Е. Джелеунова Мыстағы радиациялық міндердің пайда болу үдерісіндегі компьютерлік пішінделу

Жұмыста әртүрлі ион сәулеге түсірілген мыстағы радиациялық білімнің үдерістері қарастырылған. Каскадты ықтимал функциялардың есептеуі үшін алгоритм өзара әрекеттесулерді сан және өтімділік тереңдігі, бөлшектері бойынша радиациялық міндердің шоғырландыруына байланысты әзірленіп, есептеулер өткізілген, каскадты ықтимал функциялардың есептеулері, радиациялық міндердің шоғырландыруының жанында мыстағы иондық сәулеге түсіру пайда болатын заңдылықтар айқындалған.

Tүйін сөздер: модельдеу, ақаулар, мыс, иондар. 
А.И. Купчишин, А.А. Купчишин, Т.А. Шмыгалева, Е.В. Шмыгалев, Ш.Е. Джелеунова Компьютерное моделирование процессов радиационного дефектообразования в меди

В работе рассмотрены процессы радиационного дефектообразования в меди, облученной различными ионами. Разработан алгоритм для расчета каскадно-вероятностных функций в зависимости от числа взаимодействий и глубины проникновения частиц, концентрации радиационных дефектов, проведены расчеты, выявлены закономерности, возникающие при расчетах каскадно-вероятностных функций, концентрации радиационных дефектов при ионном облучении в меди.

Ключевые слова: моделирование, дефекты, медь, ионы. 